\title{
DEVELOPMENT OF A SIMPLE LC METHOD FOR QUANTIFICATION OF LAMOTRIGINE IN HUMAN SERUM
}

\author{
M.ALBORNOZ P., S. MENNICKENT C. , M. DE DIEGO G. AND G. RÍOS G. \\ Pharmacy, University of Concepción, P.O. Box 237, Concepción, Chile.
}

\begin{abstract}
A liquid chromatographic (LC) method for quantitative analysis of lamotrigine in human serum was developed using liquid -liquid extraction with ethyl acetate. Quantitation was achieved over the concentration range of 1.0 to $40.0 \mu \mathrm{g} / \mathrm{mL}(\mathrm{r}=0.999)$, using a mixture of acetonitrile: phosphate buffer $(0.5 \mathrm{M})$ of $\mathrm{pH} 4.5$ $(69: 31 \mathrm{v} / \mathrm{v})$ as mobile phase, with a flow of $1 \mathrm{~mL} \mathrm{~min}^{-1}$. Column was $\mathrm{C} 18(150 \mathrm{~mm}$ x $4.6 \mathrm{~mm}, 5 \mathrm{~cm}$; Merck), chloramphenicol was used as internal standard, and UV detection at $\alpha 306 \mathrm{~nm}$. The intra-assay variation was between $1.22 \%$ and $1.85 \%$ and the inter-assay was between $1.72 \%$ and $2.91 \%$. The detection limit was $0.14 \mu \mathrm{g} / \mathrm{mL}$, and the quantification limit was $0.42 \mu \mathrm{g} / \mathrm{mL}$. The method proved to be accurate, with a recovery between $94.02 \%$ and $109.95 \%$, with RSD not higher than $2.91 \%$ and was selective for lamotrigine (Rs between lamotrigine and chloramphenicol was 4.9). This method was successfully applied to quantify lamotrigine in patient serum samples.

In conclusion, the method is precise, accurate, reproducible and selective for the analysis of lamotrigine in human serum. Therefore, it could be an important tool to evaluate drug level in this matrix and, of this way, to obtain a better drug effect.
\end{abstract}

Keywords: Lamotrigine, antiepileptics; human serum; liquid chromatography.

\section{INTRODUCTION}

Lamotrigine (LTG) (Figure 1) [1] is a phenyltriazine derivative used as an anticonvulsant drug in the management of partial seizures with or without secondary generalization, in adults and children 2 years of age or older.

LTG also is used as monotherapy in patients converting from monotherapy with a hepatic enzyme-inducing anticonvulsant agent (e.g., carbamazepine, phenytoin) or a hepatic enzyme-inhibiting agent (as valproic acid). Addition or discontinuance of hepatic enzyme-inducing drugs or hepatic enzyme-inhibiting drugs may require modification of the dosage of LTG, to avoid recurrence of epileptic symptoms. Moreover, although plasma concentrations of LTG have been associated with efficacy in the prevention of epileptic seizures, the therapeutic ranges of LTG vary between individuals, especially enzymes and isoenzymes that affect plasma LTG levels [2-12]. Renal replacement therapy also influenced plasma concentrations of LTG [13-14]. Therefore, LTG should be quantitatively detected in the blood of patients to avoid drug toxicity caused by individual differences and environmental and pathological changes in the process of drug taking. Therapeutic plasma concentrations of LTG are between $1.0 \mu \mathrm{g} / \mathrm{mL}$ and $18.1 \mu \mathrm{g} / \mathrm{mL}$, with mean plasma level of $5.9 \mu \mathrm{g} / \mathrm{mL}$ [15].

The detection of antiepileptic drugs in human blood is challenging because of their low contents and the interference of complex matrices. In this way, .to control individual plasma LTG levels through the selection of appropriate dosing regimens, we developed a fast and simple method to detect serum concentrations of LTG over its therapeutic range by liquid chromatography.

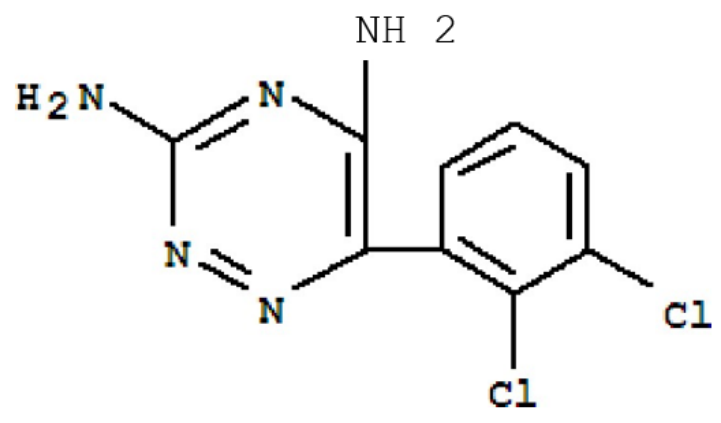

Figure 1. Chemical structure of Lamotrigine.

For determination of LTG in human blood, studies by HPLC [16-31], chemometric [32] and HPTLC [33-34] were found. Many of them need special equipment and are expensive, difficult to carry out and they require a long time for analysis. The major importance and novelty of this work is that the method is simple and economical.

\section{EXPERIMENTAL}

\subsection{Material}

\subsubsection{Apparatus}

For the HPLC method, a Merck Hitachi HPLC supplied with a UV-VIS spectrophotometer detector and a data processor (Merck, Darmstadt, Germany), were used.

Other instrumentations used were WLW Centrifuge (Germany), Heidolph shaker Metrohm (USA), and Reacti-Vap evaporator Thermo Fisher Scientific (Waltham, MA, USA).

\subsubsection{Chemicals and reagents}

Standard of LTG (98.21\% purity) and chloramphenicol (98.55\% purity) were purchased from Sigma- Aldrich (St. Louis, MO). Methanol and acetonitrile were obtained from Merck (Darmstadt, Germany). All of the reagents were HPLC grade.

\subsection{Methods}

\subsubsection{Standard solutions}

Stock solutions containing $200 \mu \mathrm{g} / \mathrm{mL}$ of LTG were prepared in methanol. Separate solutions were prepared for the calibration standards and quality control samples. These solutions were diluted immediately before use with methanol, to obtain working solutions of 1.0, 5.0, 10.0, 20.0 and $40.0 \mu \mathrm{g} / \mathrm{mL}$ for the analysis of LTG in human serum. All solutions were stored at $4{ }^{\circ} \mathrm{C}$ for about two days. Before injections, sample treatment was made for all of solutions.

\subsubsection{Spiking procedure for calibration and quality control (QC) samples}

The calibration samples were prepared immediately before use by spiking 1 $\mathrm{mL}$ of pooled human blank serum with $0.1 \mathrm{~mL}$ of a convenient working solution in methanol. Quality control samples $(1.0,10.0$ and $40.0 \mu \mathrm{g} / \mathrm{mL})$ were used to determine the intra and inter-assay precision and accuracy of the method.

Drug-free serum used for the validation of the method was obtained from healthy volunteers. 


\subsubsection{Samples}

Blood of patient volunteers $(n=5)$ using LTG as treatment for epileptic conditions were used for quantitative drug determination from serum. Venous blood samples were heated at $37^{\circ} \mathrm{C}$ and later centrifuged to obtain serum. Serum samples were frozen at $-20^{\circ} \mathrm{C}$ pending analysis (about two days).

The volume of serum used was $2 \mathrm{~mL}$. Samples and standards were applied three times, each. Standards used were at concentrations of 1.0, 10.0 and 40.0 $\mu \mathrm{g} / \mathrm{mL}$.

\subsubsection{Extraction procedure}

Blank serum and human serum samples were stored at $-20{ }^{\circ} \mathrm{C}$ until required for analysis. Serum samples, calibration and quality control samples were thawed at room temperature. Immediately after thawing, $2 \mathrm{~mL}$ of sample was processed by adding $25 \mu \mathrm{L}$ of chloramphenicol (internal standard) $(5 \mu \mathrm{g} / \mathrm{mL}), 1 \mathrm{~mL}$ of $\mathrm{NaOH} 0.1 \mathrm{~N}$ and $10 \mathrm{~mL}$ of ethyl acetate, which was subsequently vortexed and centrifuged for 5 minutes at $3000 \mathrm{rpm}$. Then, organic phase was evaporated under a gentle steam of dry nitrogen at $37^{\circ} \mathrm{C}$. The residue was dissolved in $200 \mu \mathrm{L}$ of mobile phase and stored at the freezer until its analysis.

All the procedure was accomplished under safety conditions.

Chloramphenicol was chosen as internal standard because it provides a signal that is similar to the analyte signal at the objective concentration and two signals are easily distinguishable by the instrument without interference between each to other.

\subsubsection{Chromatography}

HPLC analyses were carried out on a C18 $150 \mathrm{~mm}$ x $4.6 \mathrm{~mm}, 5 \mathrm{~cm}$ (Merck, Darmstadt, Germany) column with a flow rate of $1 \mathrm{~mL} \mathrm{min-}{ }^{1}$, using $306 \mathrm{~nm}$ as a work wavelength. Chromatographic run was 3 minutes.

Mobile phase was a mixture of acetonitrile: phosphate buffer $(0.5 \mathrm{M})$ of $\mathrm{pH}$ $4.5(69: 31 \mathrm{v} / \mathrm{v})$.

\subsubsection{Stability study}

To establishment the stability of LTG samples, in normal storage conditions, the following study was performed: six extraction solutions were used at three different concentrations: $1.0,10.0$ and $40.0 \mu \mathrm{g} / \mathrm{mL}$. These solutions were stored at three different conditions: freezer temperature, room temperature with light protection, and room temperature without light protection. Concentration determination was evaluated at $0,1,4,7,11$ and 15 days of storage. Each sample was determined by duplicated. First day corresponded to $100 \%$. Each day internal standard was added.

\subsubsection{Method validation}

The validation of the developed LC method was carried out according to Bioanalaytical method Validation guidelines [35].

\section{RESULTS AND DISCUSION}

\subsection{Method Optimization}

Different conditions for sample extraction and chromatographic conditions were evaluated for optimal results.

The optimal mobile phase was those with solvent system that would give optimal separation of LTG and chloramphenicol $(\mathrm{R}=4.9)$ and good peak symmetry.

Wavelengths of $306 \mathrm{~nm}$ allows a complete resolution of the peaks with clear baseline separation.

Sample extraction was optimized to obtain a simple procedure, with very good recoveries from spiked serum samples.

The developed method enables lower RSD for intra-day and inter day precision and better accuracy compared with other methods to quantitative determination of LTG in human blood, as can be observed in Table 1. Moreover, the most of other methods are more complicated and slower than the proposed method.
Table 1. Comparison between values obtained using proposed method and other methods founded for quantitative determination of LTG in human blood.

\begin{tabular}{|l|c|c|c|}
\hline \multicolumn{1}{|c|}{ METHOD } & $\begin{array}{c}\text { LINEARITY } \\
\text { RANGE } \\
(\boldsymbol{\mu g} / \mathbf{m L})\end{array}$ & $\begin{array}{c}\text { PRECISION } \\
(\text { RSD })(\%)\end{array}$ & $\begin{array}{c}\text { ACCURACY } \\
(\% \text { RECOVERY })\end{array}$ \\
\hline $\begin{array}{l}\text { DEVELOPED } \\
\text { METHOD }\end{array}$ & $1.0-40.0$ & $1.2-2.9$ & $94-109$ \\
\hline Serralheiro et al & $0.1-50.0$ & $\approx 12.1$ & N.A \\
\hline Vidal, Pascual and Pou & N.A & $2.4-9.1$ & N.A \\
\hline Vermeij and Edelbroek & N.A & $\approx 1.9$ & N.A \\
\hline Serralheiro et al & N.A & $\approx 12.1$ & $78-101$ \\
\hline Bompadre et al & N.A & $1.8-6.7$ & $\approx 98$ \\
\hline Cheng, Chou, Hu & $0.1-5.0$ & $\approx 8.1$ & N.A \\
\hline $\begin{array}{l}\text { Ferreira, Rodrigues, } \\
\text { Amílcar and Alves }\end{array}$ & $0.2-20.0$ & $8.1-15.4$ & $62-97$ \\
\hline $\begin{array}{l}\text { Torra, Rodamilans, } \\
\text { Arroyo and Corbella }\end{array}$ & $0.2-20.0$ & $1.8-6.7$ & $\approx 90$ \\
\hline Contin et al & N.A & $\approx 10$ & $97-103$ \\
\hline
\end{tabular}

N.A: no available (the most of papers only allowed revised the abstracts).

\subsection{Calibration curves}

Calibration curves were constructed over the concentration range of $1.0 \mu \mathrm{g} / \mathrm{mL}$ to $40.0 \mu \mathrm{g} / \mathrm{mL}$ for LTG in human serum. Each solution was injected three times. This range includes the range of therapeutic concentrations of LTG in serum $(1.0 \mu \mathrm{g} / \mathrm{mL}$ and $18.1 \mu \mathrm{g} / \mathrm{mL})$ [15]. Standard curves were constructed by plotting the peak area ratio of the analyte to the internal standard as a function of the concentration added.

The mean equation (curve coefficients \pm standard deviation) for the calibration curve $(\mathrm{n}=5)$, obtained from five points, was $y=0.032 \mathrm{x}+0.016( \pm 0.2)$ with a correlation coefficient, $r=0.999$, for LTG in human serum.

\subsection{Precision and accuracy}

The intra-assay and inter-assay precision, as intra/inter accuracy, were calculated at low (L), medium (M), and high $(\mathrm{H})$ quality control levels Three replicates were prepared for each concentration and injected three times in three different analytical run each.

Inter-assay precision and inter-assay accuracy were done for three days.

Intra-assay and inter-assay included the sample extraction step.

The precision and the accuracy of the assay were measured by the relative standard deviation (RSD) over the concentration range. LTG solutions were of $1.0,10.0$ and $40.0 \mu \mathrm{g} / \mathrm{mL}$. RSD for intra -assay study was between $1.22 \%$ and $1.85 \%$, and for inter-assay was between $1.72 \%$ and $2.91 \%$ (Table 2).

Accuracy was calculated from the test results as the percentage of analyte recovered by the assay, determined by linear regression equation of peak area versus. drug concentration. Accuracy was between $94.02 \%$ and $109.95 \%$, (Table 3).

The accuracy and precision did not exceed $2.91 \%$ of RSD at any level. Precision criteria for an assay method for drugs in biological fluids are that the precision will be $5 \%$ to $10 \%$ (RSD) [35].

The results are presented in Table 2 (precision) and Table 3 (accuracy). Recovery, comparing drug concentration in samples with and without extraction step (matrix effect), is shown at 3.6 section.

Table 2. Precision study for LTG human serum.

\begin{tabular}{|c|c|c|}
\hline Concentration $(\mu \mathrm{g} / \mathrm{mL})$ & RSD Intra-assay & RSD Inter-assay \\
\hline 1.0 & 1.85 & 2.91 \\
\hline 10.0 & 1.64 & 1.84 \\
\hline 40.0 & 1.22 & 1.72 \\
\hline
\end{tabular}


Table 3. Accuracy study of LTG in human serum.

\begin{tabular}{|c|c|c|}
\hline Real Concentration $(\mu \mathrm{g} / \mathrm{mL})$ & \% Recovery & RSD \\
\hline 1.0 & 94.02 & 2.87 \\
\hline 10.0 & 100.85 & 2.76 \\
\hline 40.0 & 109.95 & 1.89 \\
\hline
\end{tabular}

\subsection{Detection and quantification limits}

Detection and quantification limits (LOD and LOQ), were calculated using concentrations in the lower range of linear calibration curve $(0.5-1.0-1.5 \mu \mathrm{g} / \mathrm{mL})$. LOD was $0.14 \mu \mathrm{g} / \mathrm{mL}$ and LOQ was $0.42 \mu \mathrm{g} / \mathrm{mL}$ for LTG in human serum. All of values were calculated using the equations [35]: $\mathrm{LOD}=3.3 \mathrm{\sigma} / \mathrm{b} ; \mathrm{LOQ}=10$ $\sigma / b$. These values were experimentally verified.

\subsection{Selectivity}

To the study of method selectivity, the first step was analyzed blank human serum samples, to compare these chromatograms with those obtained from spiked samples with LTG and the IS. No interference was observed in drug free samples (figure 2).

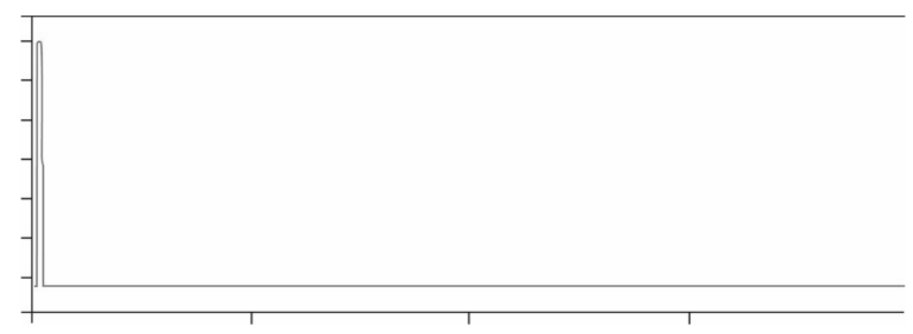

Figure 2. Blank serum.

As second step, we studied resolution between LTG and the IS, chloramphenicol. Both compounds were well separated, with a resolution (Rs) value between both peaks up 4.9 (Figure 3).

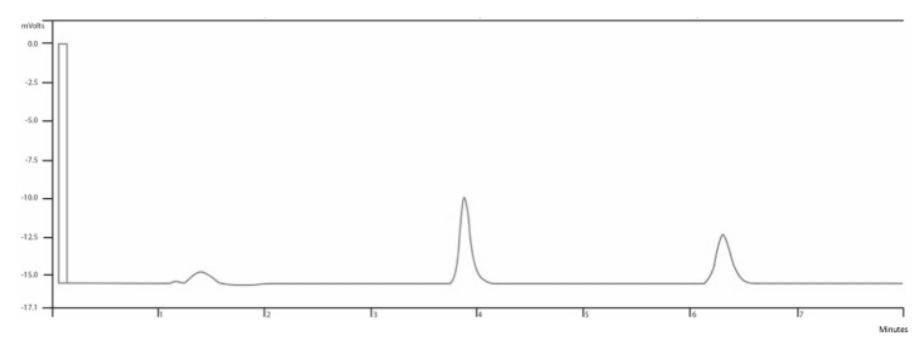

Figure 3. Selectivity between LTG and internal standard (chloramphenicol). Peak $n^{\circ} 1$ : LTG. Peak $n^{\circ} 2$ : chloramphenicol.

\subsection{Extraction recovery (matrix effect)}

The extraction recovery of LTG and IS from serum was studied at concentrations of $1.0,10.0$ and $40 \mu \mathrm{g} / \mathrm{mL}$ for the drug, and $1.5 \mu \mathrm{g} / \mathrm{mL}$ for the IS. The extraction recoveries were calculated by comparing the LTG and IS concentrations obtained from the samples that had been exposed to extraction procedure, to those obtained from the solutions added to the matrix after the extraction. The extraction recovery of LTG from human serum ranged from 90.8 $\%$ to $93.7 \%$, and the IS extraction recoveries were found between $90.6 \%$ and $92.7 \%$.

\subsection{Stability}

Stability study of LTG in human serum was done with samples stored at -20 ${ }^{\circ} \mathrm{C}$. Quality control solutions were prepared at days $0,1,4,7,11$ and 15 days. LTG concentrations ranged between $94.5 \%-96.4 \%$.

\subsection{Application of the method}

This method was used to measure the concentration of LTG in serum of volunteer patients $(\mathrm{n}=5)$ using this drug as medication for epilepsy, for at least six months. The LTG concentration was between $3.0 \mu \mathrm{g} / \mathrm{mL}$ and $16.4 \mu \mathrm{g} / \mathrm{mL}$ in the serum of volunteers (all of these values were at therapeutic range). The drug administration time is important, to ensure a steady state drug concentration, but the periodicity of sampling is not relevant, because only one sample is necessary for each patient to prove the developed analytical method in real samples.

\section{CONCLUSIONS}

The developed method was linear between the concentrations range expected, precise, accurate, sensible, and selective for the quantitative determination of LTG in human serum. As difference of other analytical methods founded in bibliography to quantify LTG in biological fluids, the proposed method exhibits better LOD, LOQ, selectivity, RSD for intra-day and inter-day precision, and is simple. Analytical methods to quantify LTG in blood are the great interest because this drug, as other antiepileptic drugs, needs to be used in the long term and should be quantitatively detected in the blood of patients to avoid drug toxicity caused by individual differences, polytherapy and environmental and pathological changes in the process of taking. The detection of antiepileptic drugs in human blood is challenging because of their low contents and the interference of complex matrices.

\section{ACKNOWLEDGEMENTS}

The authors would like to thank the Research Council at the University of Concepción (Project 219.074.062-M).

This work is part of the Thesis of Master in Pharmaceutical Sciences (University of Concepción, Chile) of Miss Milenka Albornoz.

\section{ETHICAL STATEMENT}

\section{Funding}

Project 219.074.062-M, Ethical Committee of Concepción University, Chile, and Patient Informed Consent.

\section{Disclosure of potential conflicts of interest}

Sigrid Mennickent: she has no conflict of interest. Milenka Albornoz: she has no conflict of interest.

Marta de Diego: she has no conflict of interest.

Gisela Ríos: she has no conflict of interest.

\section{Ethical approval}

All procedures performed in studies involving human participants were in accordance with the ethical standards of the Ethical Committee of University of Concepción, Chile, according with the 1964 Helsinki Declaration (JAMA 2013 Nov 27; 310 (20): 2191-4. DOI:10.1001/jama.2013.281053), and its later amendments or comparable ethical standards.

\section{REFERENCES}

1. M, Williams. The Merck Index: An Encyclopedia of Chemicals, Drugs, and Biologicals, Merck \& Co. Inc, New Jersey, 2013.

2. Hardman, J. Limbird, L. Las Bases Farmacológicas de la Terapéutica, Mc Graw-Hill, México, 2006.

3. Mc.Evoy, G. AHFS Drug Information. Ed. Bethesda, American Society of Health- System Pharmacists, Rockwile, E.E.U.U, 2015.

4. Sweetman, S. Martindale. Guía Completa de Consulta Farmacoterapéutica. Pharma Editores S.L, Barcelona, 2006.

5. W. Froscher, F. Keller, H. Vogt, G. Kramer, Epileptic Disord. 4, 49-56 (2002).

6. B.B. Brzakovic, S.D. Vezmar Kovacevic, K.M. Vucicevic et al, J Clin. Pharm. Ther. 37, 693-7 (2012).

7. A.O, Baldoni, P. Freitas-Lima P, F.I. de Santi Ferreira et al, Clin. Exp. Pharmacol. Physiol. 43, 685-9 (2016).

8. L. Liu, L, Zhao, Q. Wang, F. Qiu, X. Wu, Y. Ma, Eur. J. Clin. Pharmacol. 71, 1341-7 (2015)

9. K. Inoue, Y. Yamamoto, E. Suzuki et al, Eur. J. Clin. Pharmacol. 72, 555-62 (2016).

10. Q. Wang, M. Liang, Y. Dong et al, Drug Metab. Pharmacokinet. 30, 209-13 (2015).

11. Y. Yamamoto, Y. Inoue, K. Matsuda, Y. Takahashi, Y. Kagawa, Biol. Pharm. Bull. 35, 487-93 (2012). 
12. Y. Yamamoto, Y. Takahashi, K. Imai et al, Drug Metab. Pharmacokinet. 30, 214-20 (2015).

13. K.R. Kaufman, Bipolar Disord.12, 446-9 (2010).

14. K.S. Smetana, A.M. Cook, M.L. Bastin, D.R. Oyler, J. Crit. Care 36, 116-24 (2016).

15. P. Douglas-Hall, D. Olubanke, F Gaughran, A.Bile, D.Taylor, Therapeutic Advances in Psycopharmacology (TPP) 7, 17-24 (2016).

16. O. Beck, I. Ohman, H.K. Nordgren, Ther. Drug Monit. 28, 603-7 (2006).

17. E Vidal, C Pascual, L Pou, J. Chromatogr. B. 736, 295-8 (1999).

18. S. Itabashi, R. Bito, M. Nishina et al, Neuropsychopharmacology reports 39 , 48-55(2019).

19. N. Jebabli, H.El Jebari, R. Charfi, M. Lakhal, A. Klous, S. Trabelsi, I. Salouage, Tunis Med. 93, 565-56 (2015).

20. A. Ferreira, M. Rodrigues, F. Amílcar, G.Alves, J.Chromat.Sci. 54, $1352-$ 1358 (2016)

21. S. Jin, Q. Zhao, D. Zhang, J. Anal. Sci. Technol. 10, 36 (2019).

22. S. Itabashi, R. Bito, M. Nishima, M. Fukumoto, M. Soda, M. Doi, S. Usui, K. Kitaichi, Neuropshycopharmalogy Reports 339, 48-55 (2019).

23. M. Torra, M. Rodamilans, S.Arroyo, J.Corbella, Ther. Drug Monit. 22, 621625 (2000).

24. E. Greiner-Sosanko, S. Giannoutsos, D. Lower, M. Virji, M. Krasowski, J. Chromat. Sci. 45, 617-622 (2007).
25. H. Wang, Y. Sun, S. Xu, T. Lu, Y. Chen, L. Zhao, J. Chinesse Pharm. Sci. 27, 832-839 (2018).

26. M. Contin, S. Mohamed, C. Candela, F. Albani, R.Riva, A.Baruzzi, J. Chromatogr. B. 878, 461-465 (2010).

27. A. Serralheiro, G.Alves, A. Fortuna, M. Rocha, A. Falcäo., J Chromatogr. B. 925 (2013).

28. S. Bompadre, A. Tagliabracci, M. Battino, R. Giorgetti, J. Chromatogr. B. 863, 177-180 (2008).

29. C.L, Cheng, C.H. Chou, O.Y. Hu, J. Chromatogr. B. 817, 199-206 (2005)

30. L. Zufia, A. Aldaz, N. Ibañez, C. Viteri, J. Pharm. Biomed Anal. 49, $547-$ 553 (2009)

31. T.A.C. Vermeij, P.M. Edelbroek, J. Chromatogr. B. 857, 40-46 (2007).

32. E. Gaies, M. Bouhlel, R. Charfi et al, IJPSR 2018.

33. L. Antonill, V. Brusadin, F. Filipponi, J. Pharm. Bioanal. 56, 763-770 (2011)

34. S. Mennickent, R. Fierro, M. Vega, M. de Diego, C.G. Godoy, JPC 24, 222 226 (2011).

35. Bioanalytical method Validation. Guidance for Industry. U.S. Department of Health and Human Services Food and Drug Administration, E.E.U.U, 2018. 